\title{
Dominant macrobenthic populations experience sustained impacts from annual disposal of fine sediments on sandy beaches
}

\author{
Lisa M. Manning ${ }^{1,3}$, Charles H. Peterson ${ }^{1, *}$, Melanie J. Bishop ${ }^{2}$ \\ ${ }^{1}$ University of North Carolina at Chapel Hill, Institute of Marine Sciences, Morehead City, North Carolina 28557, USA \\ ${ }^{2}$ Department of Biological Sciences, Macquarie University, New South Wales 2109, Australia \\ ${ }^{3}$ Present address: National Oceanic and Atmospheric Administration, 1315 East-West Highway, SSMC3, Silver Spring, \\ Maryland 20910, USA
}

\begin{abstract}
Despite increasing use of dredged materials as beach fill to protect coastal property and public beaches from storm damage, knowledge of how this practice affects sandy beach ecosystems remains poor. We coupled field monitoring of 2 successive beach disposal events with mesocosm experiments to assess mechanisms of ecological effects of fine sediment disposal. Macrobenthic sampling on Topsail Island, North Carolina, revealed that disposal of dredge spoils transformed beach grain sizes from medium to fine sand. Water sampling documented substantially elevated surf-zone turbidity during and occasionally after sediment deposition. When disposal occurred before spring invertebrate recruitment to the beach, it negatively influenced recruitment of the mole crab Emerita talpoida and the amphipod Parahaustorius longimerus. When disposal followed recruitment, it affected abundances of the bean clam Donax variabilis and 3 species of haustoriid amphipods negatively, and abundance of the spionid polychaete Scolelepis squamata positively. Effects lasted for the full warm season, and suppressions of invertebrate abundances were repeated across successive annual disposal events. In mesocosms, turbidity matching that induced in the field slowed growth of clams and modified habitat choices by predatory fishes. Hence, annual disposal of fine-grained dredge spoils on these sandy beaches maintained depressed abundances of 5 of 6 macroinvertebrate prey of shorebird and surf fish, without sustaining elevated volumes of beach sediments as long as a year. Implementation of disposal projects before the beginning of the seasonal recruitment of benthos resulted in fewer negative impacts on abundance than disposal projects conducted after the recruitment season, probably reflecting a more universal risk from burial and suffocation.
\end{abstract}

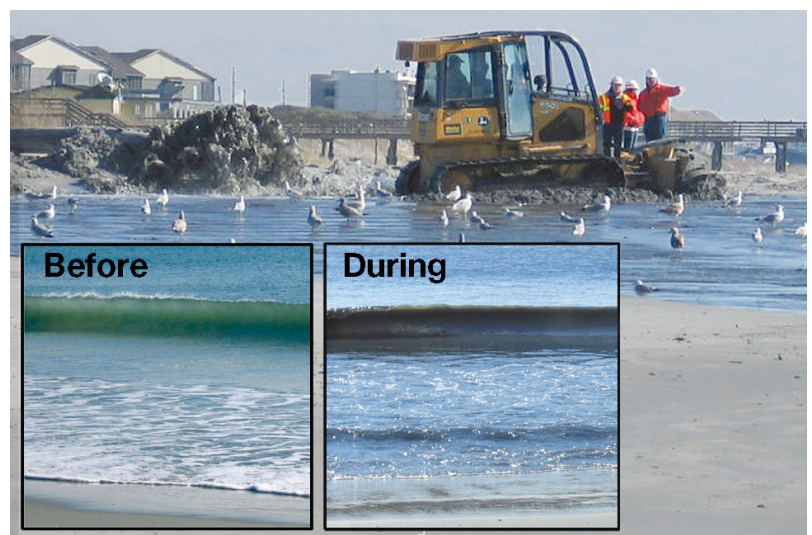

Disposal onto a sandy beach of sediments dredged from a navigation channel suppresses abundances of most intertidal invertebrates and increases surf-zone turbidity (insets).

Image: Stephen R. Fegley

KEY WORDS: Beach nourishment $\cdot$ Coastal erosion · Fine sediment disposal $\cdot$ Sandy beach $\cdot$ Sea-level rise $\cdot$ Soft sediments $\cdot$ Surf fish $\cdot$ Turbidity

$$
\text { Resale or republication not permitted without }
$$
written consent of the publisher

\section{INTRODUCTION}

Sandy beaches are threatened ecosystems (Schlacher et al. 2007, Defeo et al. 2009, Dugan et al. 2010), due to rising sea levels and enhanced frequency of intense storms (IPCC 2007) as well as through interactions between manifestations of climate change and management responses intended to counteract 
erosion (Dugan et al. 2008, Schlacher et al. 2012). Sea walls and other hard structures have historically been installed on beaches to protect beachfront development, with variable success, often exacerbating beach erosion (Pilkey \& Wright 1988) and in many cases causing measurable ecological degradation of beach ecosystems (e.g. Dugan et al. 2008, Jaramillo et al. 2012). Consequently, beach nourishment, whereby sediments from elsewhere are added to beaches to counteract erosion, has become the favored management response (Valverde et al. 1999) along ocean and lake beaches around the world (e.g. Basco 1999, Hanson et al. 2002, Cooke et al. 2012).

It is often assumed that because sandy beaches are physically dynamic, the organisms that live in this environment are adapted to the stresses associated with sediment deposition. Early studies of impacts of beach nourishment on abundance of intertidal invertebrates (Hayden \& Dolan 1974, Gorzelany \& Nelson 1987) showed effects lasting just a few months. Flaws in the design of most studies that monitored ecological impacts of nourishment have, however, limited the inferences that can be made (Peterson \& Bishop 2005, Speybroeck et al. 2006). In a review of largely unpublished reports, Nelson (1988) concluded that after the use of sediments that are substantially finer than native beach sands, suppression of invertebrate abundance may persist through time, and the impact increases with the proportion of fine materials in the beach fill. Subsequent field studies (Rakocinski et al. 1996, Peterson et al. 2000) and reviews (Hackney et al. 1996, Greene 2002) have reinforced this view. Augmenting the coarse fraction of sediments and shell hash on the beach can have similarly large effects on the infauna, especially on burrowing bivalves (McLachlan 1996, Peterson et al. 2006, 2014).

Unfortunately our mechanistic understanding of how these impacts arise remains limited (Peterson \& Bishop 2005, Speybroeck et al. 2006). Sandy beach invertebrates may be suffocated after burial under deposited sediments (e.g. Schlacher et al. 2012), a process that may not depend greatly on the grain size of sediments deposited. Alternatively, modification of grain size via the deposition of mismatched sediments can influence larval or juvenile settlement behavior and hence, subsequent density. Timing of the sediment deposition relative to seasonal recruitment influences which of these responses may be triggered by the deposition of fill. If deposition occurs before the seasonal recruitment by the macrobenthos, then behavioral responses to sediment suitability may influence macrobenthic population abundances. On the other hand, if deposition follows seasonal recruitment, then burial and suffocation represent the likely process by which macrobenthic densities may be modified. Consequently, choosing the timing of deposition relative to seasonal recruitment may be an important management decision if one of these processes proves to have generally larger or more wide-spread impacts. Where turbidity may interfere with the ability of visually orienting fishes to detect prey, timing deposition projects to avoid seasons of intense fish predation on sandy beach benthos would be desirable (Peterson et al. 2006, Manning et al. 2013). Whether the fill sediments are finer or coarser than original sediments may also affect the ability of organisms to burrow and feed (Manning et al. 2013, Van Tomme et al. 2013, Viola et al. 2013) and influence the lifetime of fill placement (Warrick 2013).

As the demand for interventional adaptations on coasts to climate change grows (Staudinger et al. 2012), a better understanding of the mechanisms by which sandy beach ecosystems respond to and recover from disturbance, including sediment filling, is imperative. Here, we coupled field monitoring of 2 successive dredge spoil disposal events with manipulative mesocosm experiments to assess the mechanisms and extent of ecological impacts. The fill events, separated by a year, utilized sediments from maintenance dredging of a navigation channel, potentially justifiable by the dual purpose of spoil disposal as well as nourishment. Frequent sampling of control and disposal sites before, during, and after each of the disposal events assessed: (1) the rate of erosion of fill from the beach $;(2)$ the extent, magnitude, and duration of changes in sediment grain size on the beach and of turbidity in the surf zone; and (3) effects on abundances and body sizes of numerically dominant beach invertebrates. Mesocosm experiments assessed whether enhanced concentrations of suspended inorganic particles affect growth rate in the bean clam Donax variabilis, the dominant species in terms of biomass, or habitat choice by 2 common surf fishes. We hypothesized that in the event that fine sediments are rapidly eroded from the beach, impacts on fauna would be short-lived.

\section{MATERIALS AND METHODS}

\section{Study sites and monitoring design}

We assessed physical and biological effects of repeated spoil disposals on the intertidal and shallow subtidal zones of Topsail Island, North Carolina, USA 
(Fig. 1), a low-lying, transgressive barrier island with an average width of $280 \mathrm{~m}$. The island is extensively developed despite regular over-wash by storms (Cleary \& Pilkey 1996). Protection of the island's beaches and coastal development involves regular redistribution of sand from the low to the high beach by bulldozing, as well as beach filling, mostly with dredge spoils from New River Inlet and the Intracoastal Waterway (Fig. 1).

Our study considered 2 beach filling events. (1) In late April to early June 1999, $95000 \mathrm{~m}^{3}$ of dredge spoil was distributed across $350 \mathrm{~m}$ of beach at the northern end of the island. (2) In April 2000, $49000 \mathrm{~m}^{3}$ was distributed across approximately the same area. In October 1998, 6 mo prior to the first filling event, we established 2 sites within the area designated for filling, Topsail Reef I \& II (D1 \& D2) and 2 control sites, Topsail Dunes (C1) and Roger's Bay (C2) to the south of the impacted area (Fig. 1). It was not possible to intersperse disturbed and control sites, because potential reference barrier islands to the north differed in geomorphology. Nevertheless, prior to the disposal events benthic macrofaunal abundances did not display any gradient along Topsail Island. All study sites were exposed to the open ocean and experienced a mean tidal range of about $1 \mathrm{~m}$.

We conducted monthly (warm season) to 2monthly (cool season) sampling at each of the 4 study sites between October 1998 and September 2000. We sampled during morning low tides under calm ocean conditions along 3 transects extending from the base of the dune to a water depth of $1 \mathrm{~m}$. The 3 transects were $40 \mathrm{~m}$ apart, with the position of the first haphazardly determined on each sampling date, so that our samples were spatially independent in that adjacent transects could not traverse the same large patch of benthic infauna (patches of Donax spp. and
Table 1. Tidal zones (after McLachlan 1980, Peterson et al. 2006)

\begin{tabular}{|c|c|c|}
\hline No. & Tidal zone & Description \\
\hline (1) & Supratidal & $\begin{array}{l}\text { Extends from the base of the } \\
\text { dune to the high-tide drift line }\end{array}$ \\
\hline (2) & High intertidal & $\begin{array}{l}\text { Seaward of the drift line, area } \\
\text { where sand dries during low tide }\end{array}$ \\
\hline (3) & Mid-intertidal & $\begin{array}{l}\text { Remains wet during low tide } \\
\text { after gravitational water loss }\end{array}$ \\
\hline (4) & Low intertidal & $\begin{array}{l}\text { Swash zone, area of final run-up } \\
\text { and -down of waves at low tide }\end{array}$ \\
\hline (5) & Shallow subtidal & $\begin{array}{l}\text { Surf zone, from lower margin of } \\
\text { the swash zone to } 1 \mathrm{~m} \text { water } \\
\text { depth at low tide }\end{array}$ \\
\hline
\end{tabular}

Emerita talpoida can be up to $15 \mathrm{~m}$ in diameter; L. Manning pers. obs.). Along each transect, we stratified our sampling of sediments and fauna across 5 tidal zones (Table 1).

\section{Field sampling}

We measured beach profiles before and after sediment disposal (4 April and 25 June 1999, and 5 April and 15 May 2000). Within $2 \mathrm{~h}$ of low tide, a single profile was produced for each of the 4 field sites, measured from a fixed stake behind the primary dune and extending from the top of the supratidal to $1 \mathrm{~m}$ water depth in the surf zone. Vertical measurements were made using a Topcon AT-2 Autolevel and a $7.5 \mathrm{~m}$ telescoping rod, and horizontal measurements were made with a measuring tape (each to the nearest $\mathrm{cm}$ ). Profiles were used to calculate absolute and percent changes in beach sediment volume $\left(\mathrm{m}^{3}\right.$
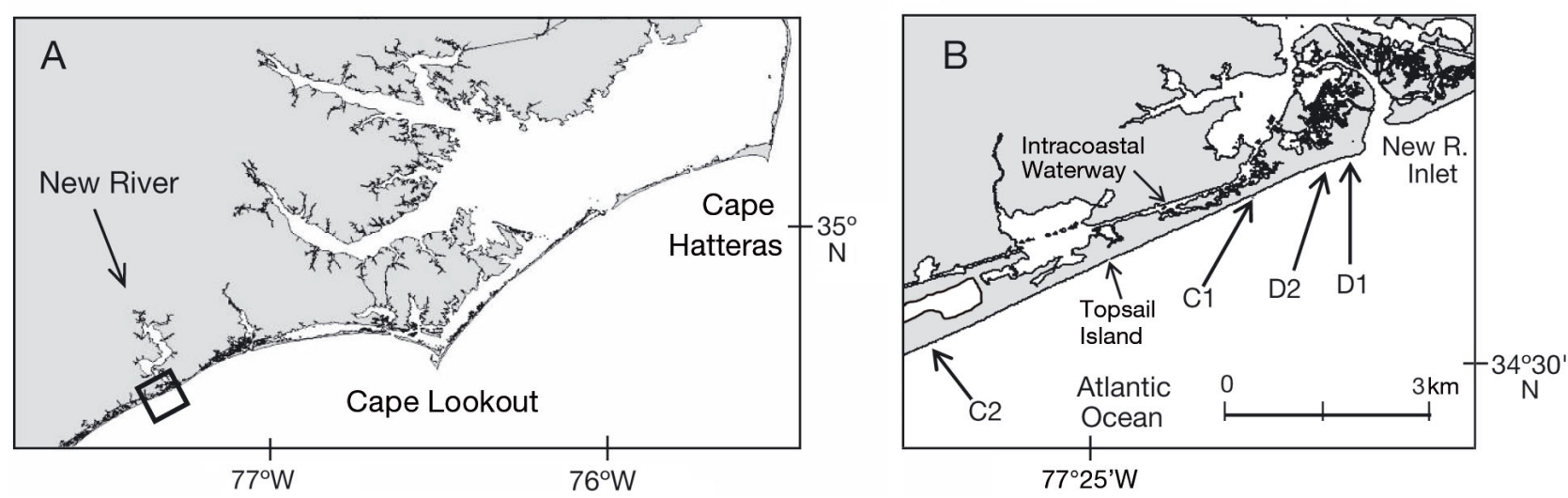

Fig. 1. Location of (A) Topsail Island, North Carolina, adjacent to New River inlet, and (B) control (C1, C2) and disposal (D1, D2) sites 
per $\mathrm{m}^{2}$ surface of beach) relative to the profile established before the first fill event. We did not monitor profiles to depth off the beach, because our primary interest was in the intertidal beach and because back beach dunes play a much greater role in inhibiting structural damage from waves under the surge of storms (Rogers 2007), which is also the motivation for bulldozing sand from low shore to the back beach.

A $4.8 \mathrm{~cm}$ diameter by $10 \mathrm{~cm}$ deep cylindrical core of sediment was collected from the middle of each tidal zone along each transect, on every sampling date. In the laboratory, each sediment core was rinsed with de-ionized water to remove salt, silt, and clay, and dried to constant weight at $90^{\circ} \mathrm{C}$. Dried samples were sieved on a $2 \mathrm{~mm}$ screen to remove gravel; a subsample of 30 to $70 \mathrm{~g}$ was taken and passed through a nested series of 9 sieves, of mesh sizes 1414, 1000, 707, 500, 354, 250, 177, 125, and $89 \mu \mathrm{m}$ (Folk 1980). The weight of each fraction (1 gravel and 10 sand) was recorded to the nearest $0.01 \mathrm{~g}$, and median grain size (in $\mu \mathrm{m}$ ) and sorting (the inverse of the spread of the grain size distribution) were calculated for each sample (Folk 1980).

We assessed turbidity of the surf zone on sampling dates between November 1998 and May 2000 by collecting two $23 \mathrm{ml}$ surface water samples from the seaward end of each transect, where water depth was 1 to $2 \mathrm{~m}$, and measuring them with a portable Orbeco-Hellige turbidity meter. On 28 May 1999 and on 5 April 2000, during active pumping of sediment slurry onto the beach, we also took 3 replicate water samples from 1 and $2 \mathrm{~m}$ water depths at distances $20 \mathrm{~m}$ up-current of and 20 and $70 \mathrm{~m}$ down-current of the discharge point. The 2 water depths (measured at high tide) were chosen to represent the swash and surf zones, respectively.

Samples for assessing the effects of beach sediment disposal on benthic macrofauna were collected using a cylindrical hand-corer of $10.1 \mathrm{~cm}$ internal diameter by $20 \mathrm{~cm}$ depth. Initially (October 1998 to June 1999), we collected 4 cores from each tidal zone along each transect, but this was later increased to 8 (between July 1999 and September 2000) due to the very low densities of many taxa, especially amphipods. Sample contents were pooled within each tidal zone and sieved over a $1 \mathrm{~mm}$ mesh, and average faunal densities computed per unit area. On each date, we measured the width of each tidal zone so that we could weight zone-specific densities of fauna by zone widths to obtain an unbiased estimate of total abundance within a $1 \mathrm{~m}$ wide transect spanning the beach width (see Brazeiro \& Defeo 1996, Peterson et al. 2006). Sieved samples were fixed in $10 \%$ borax- buffered formalin in seawater, and invertebrates were enumerated by species in the laboratory. Lengths of all bivalves (longest anterior-posterior dimension) and mole crabs (anterior-posterior length of carapace) were measured with Vernier calipers to the nearest $0.01 \mathrm{~cm}$.

\section{Clam growth under elevated turbidity}

To test the hypothesis that enhanced concentrations of suspended inorganic particles in the water reduce the growth of the filter-feeding surf clam Donax variabilis (e.g. Robinson et al. 1984), we conducted a $19 \mathrm{~d}$ mesocosm experiment (starting 29 September 1999). We compared increase in weight and shell length at low and high densities of $D$. variabilis between conditions of ambient and elevated concentrations of suspended inorganic particles.

Suspended inorganic particles were manipulated by passing Bogue Sound water through a 1400 l header-tank where it manually received pulverized, inorganic kaolin clay (Albion Kaolin Company) every $30 \mathrm{~min}$. Kaolin clay was used in experiments because: (1) it is commonly present in dredged sediments (Edge 1972, Combs et al. 1982), and (2) it has been extensively used in previous studies on effects of turbidity on fishes and invertebrates (reviewed by Wilber \& Clarke 2001). Although addition of kaolin alone meant that our treatments lacked the fine organic particles that may also be present in fill sediments, our interest here was in the capacity of the fine inorganic particles to clog gills, without modification of food availability as a result of enhancement of organic matter concentrations.

The experiment was conducted in 12 outdoor wave tanks ( $2.1 \mathrm{~m}$ long, $1.2 \mathrm{~m}$ wide, $0.6 \mathrm{~m}$ deep) situated on the northern shore of Bogue Sound, North Carolina. Each tank was partially filled with medium beach sand, which was sloped to create a deeper subtidal basin and an intertidal swash zone. At the subtidal end of each tank, waves were produced at a frequency of $2 \mathrm{~min}^{-1}$ by the continuous flow of unfiltered $\sim 35 \mathrm{ppt}$ seawater into an asymmetric trough that periodically overbalanced, rotated, and emptied (photograph in Manning et al. 2013). Water temperature ranged from 24 to $27^{\circ} \mathrm{C}$ and did not vary among tanks.

Six of the tanks, randomly assigned to the control treatment, received unfiltered seawater, which had a turbidity of 10.2 to 35.6 Nephelometric Turbidity Units (NTUs), directly from Bogue Sound. The 6 experimental tanks were maintained at a daytime 
turbidity of 80 NTUs, well within the range recorded at disposal sites during beach filling (see Fig. 4). To replicate diurnal cycles of turbidity on Topsail Island, clay addition to the head-tank was discontinued for 8 to 10 night-time hours. Clay was kept in suspension within the header-tank by bubbling air from its bottom.

Replicate tanks $(n=3)$ of each turbidity treatment were randomly assigned to a low (222 ind. $\mathrm{m}^{-2}$ ) and high (444 ind. $\mathrm{m}^{-2}$ ) clam density. Individually marked clams (20, low density; or 40, high density) of mean (+SE) lengths of $0.83+0.01 \mathrm{~mm}$ and towel-dried weights of $0.206+0.006 \mathrm{~g}$ were placed in a plastic basket (measuring $30 \times 30 \mathrm{~cm}$ with $15 \mathrm{~cm}$ depth and $0.5 \mathrm{~cm}$ mesh), and a single basket was buried in each tank so that its top edges were flush with the surface of the sediment. At the start of the experiment and after $19 \mathrm{~d}$, the anterior-posterior length of each clam was measured to the nearest $0.1 \mathrm{~mm}$ using calipers and then hand dried and weighed to the nearest $0.1 \mathrm{mg}$.

\section{Response of surf fishes to turbidity}

We conducted behavioral experiments to test whether elevated turbidity may affect the local distribution of 2 locally common surf fishes, the juvenile summer flounder Paralichthys dentatus and Florida pompano Trachinotus carolinus. A $4.2 \mathrm{~m}$ long, $1.2 \mathrm{~m}$ wide, $0.6 \mathrm{~m}$ deep outdoor tank was divided into three $1.4 \mathrm{~m}$ long zones (Zones 1 to 3) using string suspended above the surface. Water flowed into the tank at each end: Zone 1 received unfiltered seawater, while Zone 3 received either unfiltered (control) or high-turbidity (100 to 120 NTUs; experimental) seawater from the previously described header tank. Water drained out through a $9 \mathrm{~cm}$ high stand-pipe in Zone 3. An identical, but non-functional standpipe was placed in Zone 1 to remove any confounding effect of structure on experimental treatments.

Each fish was observed under 2 sets of experimental conditions, the first without (control) and the second with (experimental) enhancement of turbidity using kaolin clay. For each control run, seawater flow was shut off and a single fish was introduced to the middle zone (2) and observed under resumption of water flow after 1 min of acclimation. An observer positioned motionless alongside Zone 2 recorded the total time out of 15 min for summer flounder $(7$ to $12 \mathrm{~cm}$ in total length, TL; $\mathrm{n}=8$ ) and 5 min for Florida pompano ( 5 to $9 \mathrm{~cm} \mathrm{TL} ; \mathrm{n}=26$ ) that each fish spent in
Zones 1 and 3. Observation intervals reflected differences in mobility between species. After each fish had been observed under control conditions, it was again observed under experimental conditions differing only by addition of turbidity to Zone 3 for the experimental treatments.

\section{Statistical analyses}

We used separate univariate permutational ANOVA (PERMANOVA; Anderson 2005) to test for interacting effects of treatment and time on: (1) median grain size, (2) sediment sorting, (3) turbidity, and (4) density of dominant macrofaunal taxa by species. PERMANOVA assumes that data are independent, but does not require that data be normally distributed (Anderson 2005). The PERMANOVAs each used Euclidean distances between untransformed data. All but the PERMANOVAs of turbidity had 4 factors: Treatment (2 levels: control, disposal); Site (4 levels: C1, C2, D1, D2, nested within Treatment); Year (2 levels: 1, October 1998-September 1999; 2, October 1999-September 2000) and Month (7 to 9 levels, depending on the analysis). Month was orthogonal to Year because this sandy beach system displays strong seasonality in its ecology, which - in the absence of disturbance - causes predictable patterns in variables among months (Peterson et al. 2006). In the PERMANOVA of turbidity, we replaced the 2 factors Year and Month with the single factor Time because there was insufficient sampling in 2000 to allow contrasts across years. Separate analyses of sediment granulometry were done for each of the 5 tidal zones on the beach, as sediment properties may be expected to naturally vary across this gradient. Analyses of turbidity and fauna used transect values as replicates (see 'Field sampling' for a description of how faunal densities per $1 \mathrm{~m}$ wide transect were calculated), as our interest was in the total reduction of prey abundance for shorebird and surf fish predators. Analyses were run using unrestricted permutation of raw data, and, where significant effects were seen at $\alpha=0.05$, they were followed by pair-wise a posteriori tests to identify sources of significant differences.

Kolmogorov-Smirnov tests assessed differences in the size-frequency distributions of $D$. variabilis and E. talpoida between control and disposal sites during September of each year.

3-way PERMANOVA analyses, with 3 factors, Turbidity (2 levels: control, enhanced), Density (2 levels: low, high) and Tank (3 levels: nested within Turbidity 
and Density), tested for density-dependent effects of turbidity on the proportionate shell growth and weight gain of $D$. variabilis during the mesocosm experiment. Statistical procedures were as for the 4-way PERMANOVAs described above.

To test for behavioral responses of Florida pompano and summer flounder to turbidity, we first used 2-tailed, paired $t$-tests to confirm that there was no difference in the time fish spent in Zones 1 and 3 of the tank in the absence of turbidity. We then used 2-tailed paired $t$-tests to assess differences in time spent at the 2 ends when clear water was added to Zone 1 and turbid water to Zone 3.

\section{RESULTS}

\section{Field sampling}

At the 2 disposal sites, the beach sediment volume along our sampling transects increased by 0.94 to $0.97 \mathrm{~m}^{3} \mathrm{~m}^{-2}$ (53 to $56 \%$ relative to mean low water spring tide) from shortly before to immediately after the 1999 fill event (Fig. 2). By contrast, over the same period, 0.23 to $0.37 \mathrm{~m}^{3} \mathrm{~m}^{-2}$ of sediment (8 to $11 \%$ ) was lost from control beaches. A year after the fill event, the sediments on fill beaches had declined to levels just $0.08 \mathrm{~m}^{3} \mathrm{~m}^{-2}$ (or $2 \%$ ) below the volumes measured before the 1999 disposal event, and the control beaches to levels $0.36 \mathrm{~m}^{3} \mathrm{~m}^{-2}$ (or $10 \%$ ) below the volumes present before the 2000 fill event. In the fill event of 2000, the disposal sites exhibited an increase in sediment volume of 0.49 to $0.59 \mathrm{~m}^{3} \mathrm{~m}^{-2}$ (32 to $36 \%$ ), while the control beaches changed less than $0.04 \mathrm{~m}^{3} \mathrm{~m}^{-2}$ (or $6 \%$; Fig. 2) and in inconsistent directions.

The 1999 fill event resulted in a strong reduction in median grain size and an increase in sediment sorting at the disposal sites (PERMANOVA, significant Treatment $\times$ Year $\times$ Month interaction, see Table S1 in the Supplement at www.int-res.com/articles/ suppl/m508p001_supp.pdf; Fig. 3). At the same time, small increases in median grain size and a decrease in sediment sorting were evident on control beaches (Fig. 3). Within most tidal zones (1, 3 \& 4), the significant differences in granulometry between control and disposal sites did not persist past September 1999, 3 mo after beach filling. Immediately following the 2000 fill event, analogous differences in granulometry between disposal and control treatments were significant only within tidal zone 4 (swash). Nevertheless, at the final sampling date in September 2000, the median sediment grain size was finer at disposal than control sites in tidal zones 1 to 3 (supratidal to mid-intertidal; Fig. 3).

Active pumping and deposition of dredge spoil was occurring on 2 of the dates (28 May 1999 and 5 April 2000) when turbidity samples were collected. On both occasions, the average surf zone turbidity was significantly elevated, compared to control beaches (1999: 170 vs. 10 NTUs; 2000: 27 vs. 7 NTUs; Fig. 4; PEMANOVA, significant Time $\times$ Treatment interaction, see Table S2 in the Supplement). Additional samples (data not shown) collected in the swash and surf zones indicated turbidity levels around 300 NTUs near the point of discharge of sediment slurry and smaller but substantial elevations of both swash and surf zone turbidity to levels of 70 to 110 NTUs at distances of 20 and $70 \mathrm{~m}$ away in the down-current direction. Turbidity increases on disposal beaches were smaller on 5 April 2000, because the long-shore current on that date happened to flow from the discharge pipe away from the sampling transects. At the majority of the other sampling times, there was little difference in turbidity between disposal and control sites. An exception was July 1999, 2 mo after the 1999 pumping had ceased, when turbidity was significantly greater at disposal sites than at control sites (Fig. 4, Table S2). Additionally, at 1 sampling date (3 May 1999), when side-cast dredging was being conducted in New River Inlet, turbidity was elevated at the control relative to the disposal beaches (Fig. 4).

A total of 23 macrobenthic invertebrate species from 4 phyla (Annelida, Nemertea, Mollusca, Arthropoda) were identified. Two species (the bivalve Donax variabilis and the polychaete Scolelepis squamata) constituted $89 \%$ of the total number of organisms collected. The next most abundant taxa were the haustoriid amphipods Haustorius sp. (3\%), Amphiporeia virginiana (3\%), and Parahaustorius longimerus $(2 \%)$, as well as the mole crab Emerita talpoida (2\%). Most taxa occurred in all 5 tidal zones, although distributions were not constant across zones. D. variabilis, D. parvula, and E. talpoida were most abundant in the mid-intertidal (tidal zone 3 ) and swash zone (tidal zone 4). The haustoriid amphipods and $S$. squamata were most abundant in the surf zone (tidal zone 5).

Effects of beach filling on faunal abundances varied among the 6 most abundant taxa and between the 2 fill events (PERMANOVA, Treatment $\times$ Year $\times$ Month, Treatment $\times$ Month, and Treatment $\times$ Year interactions; see Table S3 in the Supplement; Fig. 5). In 1999, when disposal occurred prior to the recruitment of 4 of 6 sandy beach invertebrates 
Year 1: 1999

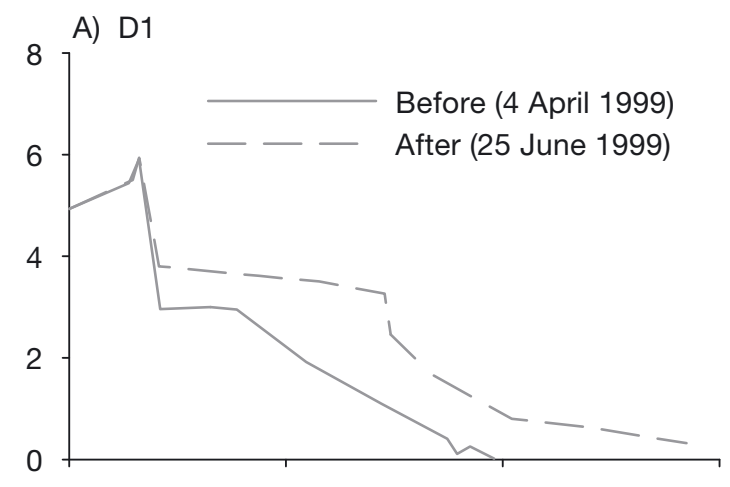

Year 2: 2000
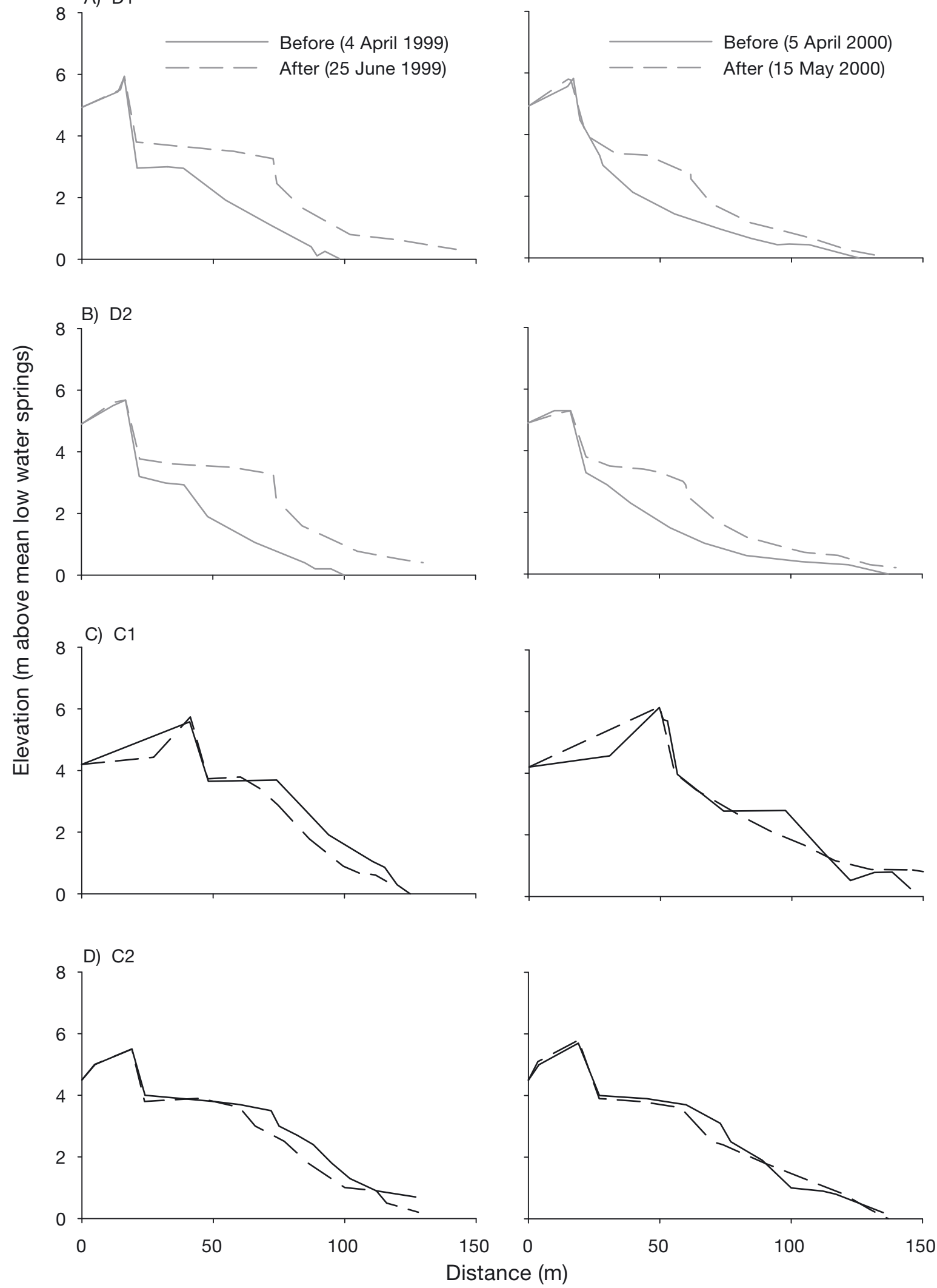

Fig. 2. Elevation profiles of $(A, B)$ disposal sites (D1 \& D2) and (C,D) control sites (C1 \& C2) before and after sediment disposal 


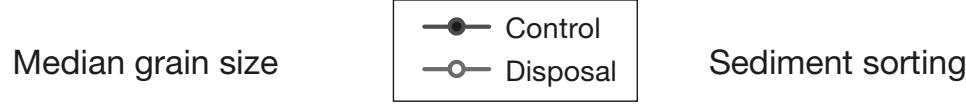
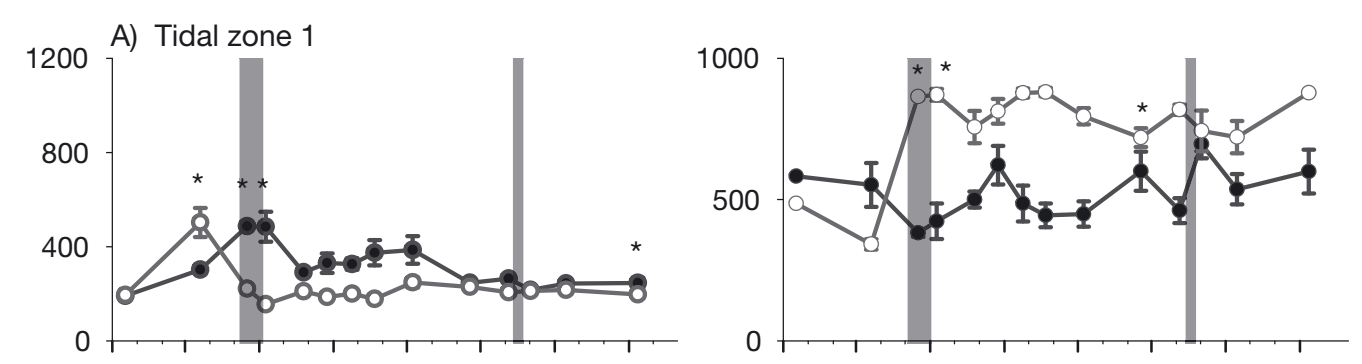

B) Tidal zone 2
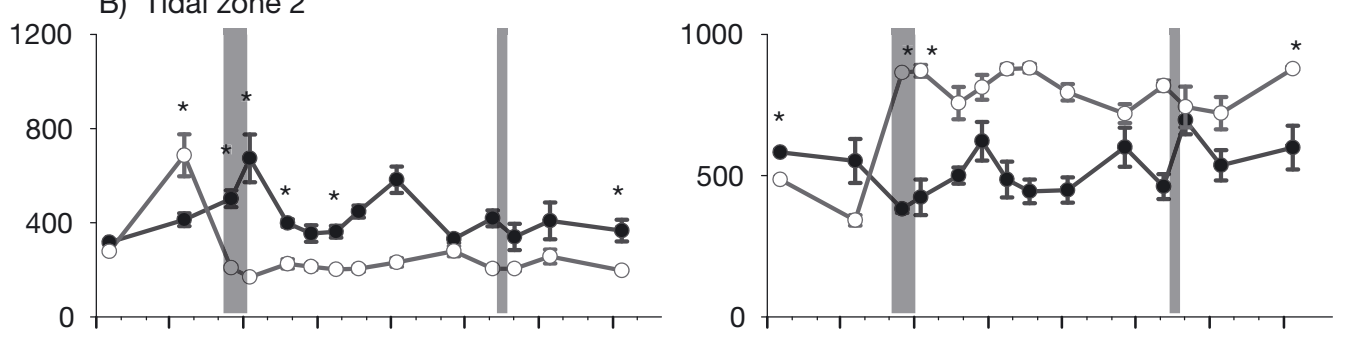

C) Tidal zone 3
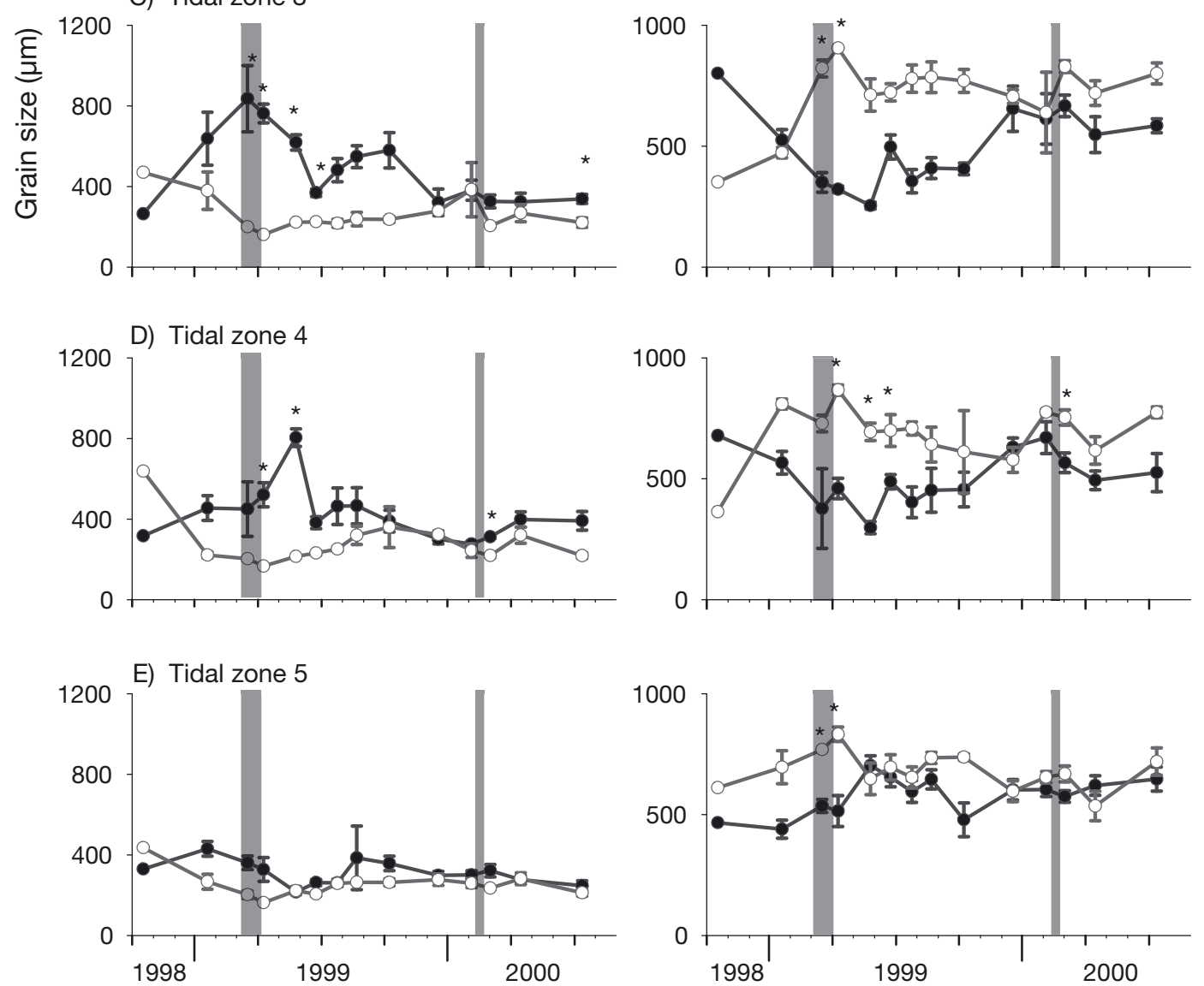

Fig. 3. Grain size and sorting of sediments (median $\pm \mathrm{SE}_{;} \mathrm{n}=6$ ) at control and disposal sites before, during (shaded areas), and after disposal events. Sorting is an index of the tightness of the grain size distribution (the inverse of variance). (*) Significant a posteriori tests for Year $\times$ Month $\times$ Treatment interactions (PERMANOVA; Table S1 in the Supplement). Tidal zones are described in Table 1 


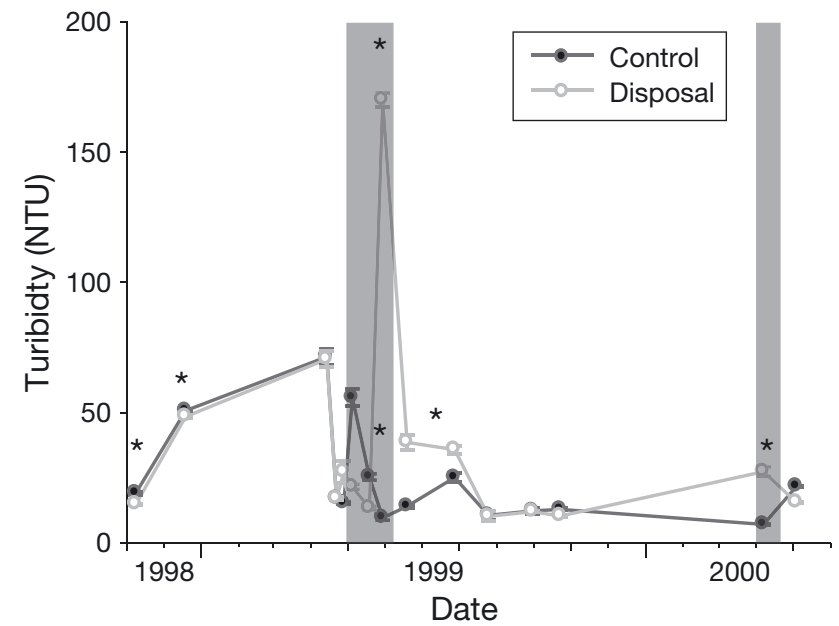

Fig. 4. Turbidity in the surf zone (mean $\pm \mathrm{SE}_{;} \mathrm{n}=6$ ) of disposal and control sites, before, during (grey shaded areas), and after disposal events. (*) Significant a posteriori tests for Year $\times$ Month $\times$ Treatment interactions (PERMANOVA; Table S2 in the Supplement)

(Fig. 5), 2 of these 4 (D. variabilis and Haustorius sp.) plus one for which the disturbance fell after recruitment had begun ( $S$. squamata) did not exhibit detectable abundance responses to the 1999 disposal. The 1999 disposal resulted in significantly reduced abundances of E. talpoida, P. longimerus and A. virginiana. Among these, E. talpoida was particularly affected, with a peak abundance at disposal sites only about $25 \%$ of the abundance at control sites. The 2000 disposal occurred after 5 of the 6 species had already begun seasonal recruitment and 4 of those 5 exhibited significant depression in subsequent warm-season abundance $(D$. variabilis, Haustorius sp., $P$. longimerus, and A. virginiana). One other, the polychaete $S$. squamata, peaked in July at disposal sites, with 3 times the abundance it attained at control sites (Fig. 5). Only E. talpoida failed to exhibit a significant response to this disposal. Thus, even though the volume of sediment added in 2000 was only half of what was added along the same shoreline sites in 1999, this disposal event, which fell after seasonal recruitment had begun, caused suppression in seasonal abundance growth in 5 species as opposed to only 3 suppressed species in 1999 when disposal occurred before recruitment began for 4 of 6 species (Fig. 5).

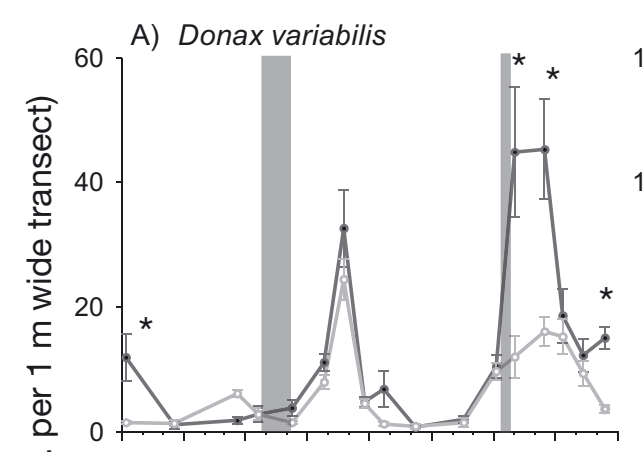

B) Emerita talpoida
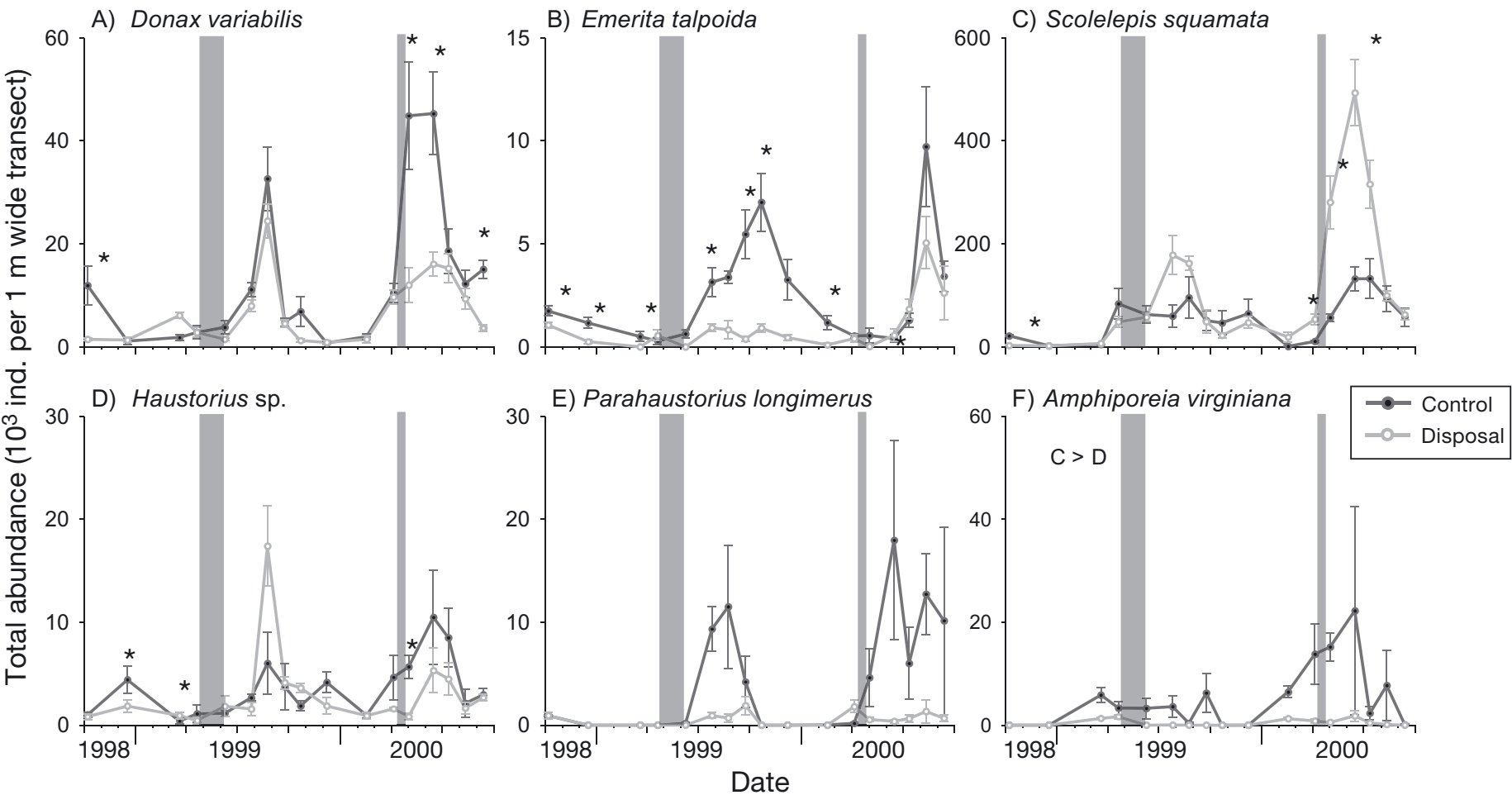

Fig. 5. Abundances (mean $\pm \mathrm{SE}_{;} \mathrm{n}=6$ ) of numerically dominant taxa of beach macroinfauna along $1 \mathrm{~m}$ wide transects running from the supratidal to the shallow subtidal zone (see Table 1) at control and disposal beaches before, during (grey shaded areas), and after disposal events. (*) Significant a posteriori tests for Year $\times$ Month $\times$ Treatment interactions (PERMANOVA; Table S3 in the Supplement). Parahaustorius longimerus displayed a significant Site $\times$ Year $\times$ Month interaction due to greater seasonal peaks in abundance on disposal than control beaches, although the magnitude of peaks also differed between control beaches. Amphiporeia virginiana displayed main effects of Treatment (disposal vs. control) 


\section{A) Donax variabilis}

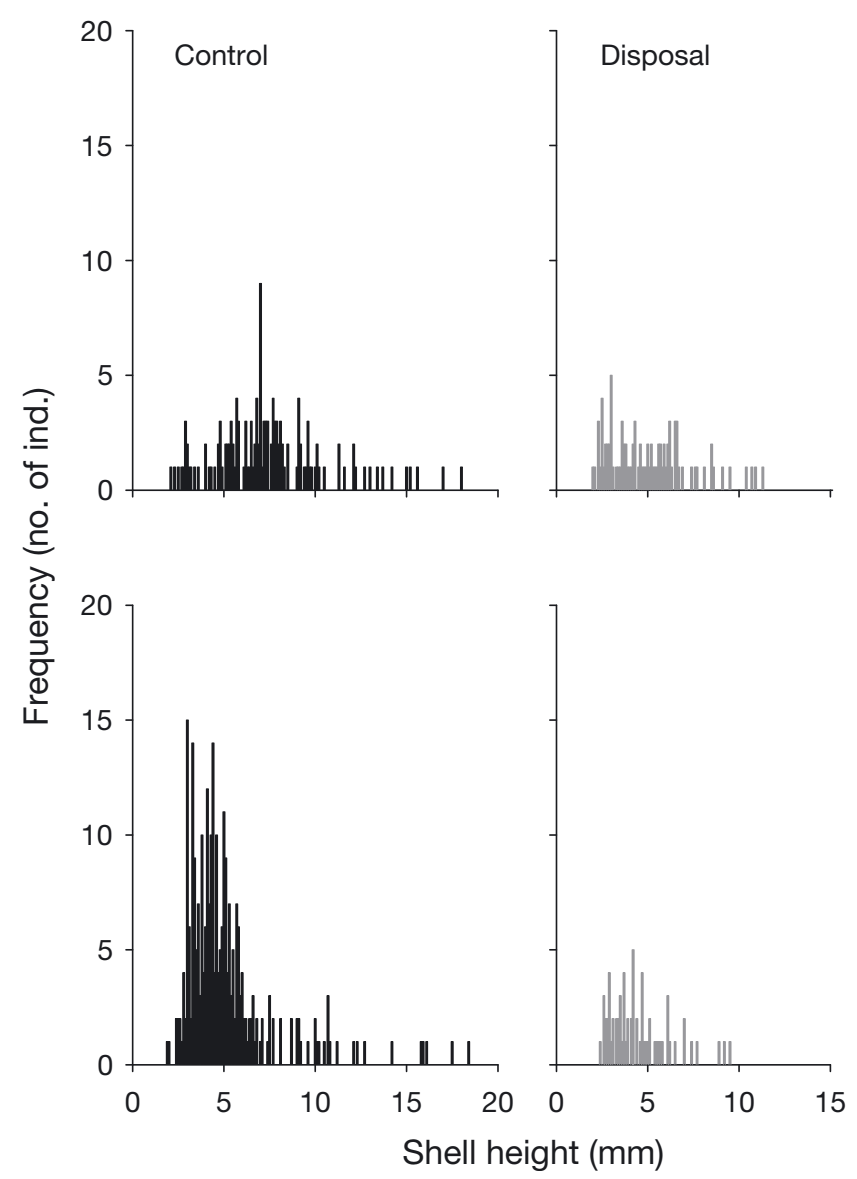

B) Emerita talpoida
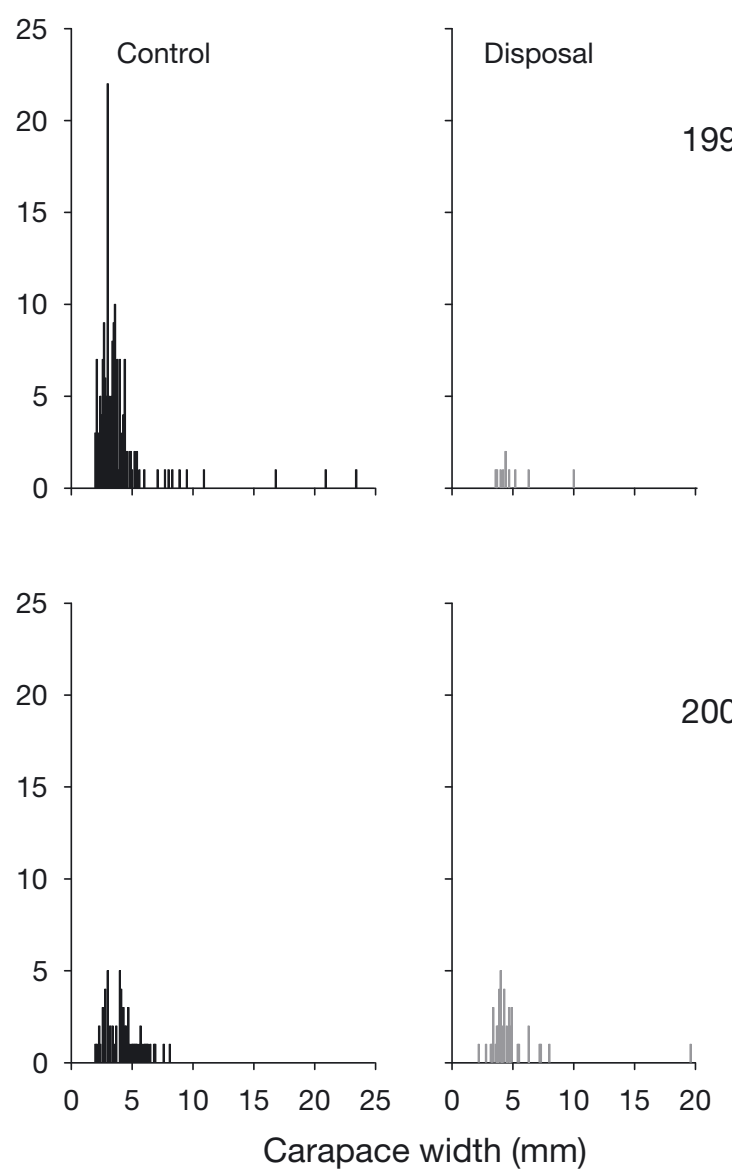

Fig. 6. Size frequency of (A) Donax variabilis and (B) Emerita talpoida at control and disposal sites during September abundance peaks of each year

Following each disposal event, differences in the size-frequency distributions of $D$. variabilis were apparent (Fig. 6; Kolmogorov-Smirnov tests: 1999, $D=0.60, \mathrm{df}=1, \mathrm{p}<0.001 ; 2000, D=0.45 \mathrm{df}=1, \mathrm{p}<$ 0.001 ). At the disposal sites, $D$. variabilis $>15 \mathrm{~mm}$ in shell length were notably absent, and the median shell lengths were consequently lower (1999: $4.8 \mathrm{~mm}$; 2000: $4.2 \mathrm{~mm}$ ) than at control sites (1999: $7.0 \mathrm{~mm}$; 2000: $4.5 \mathrm{~mm}$ ). Differences in the size-frequency distributions of E. talpoida between disposal and control sites were smaller than those for $D$. variabilis (Fig. 6; Kolmogorov-Smirnov tests: $1999, D=0.15, \mathrm{df}=1, \mathrm{p}=$ $0.04 ; 2000, D=0.26, \mathrm{df}=1, \mathrm{p}=0.03$ ). In 1999, when very few E. talpoida were recorded at disposal sites, the median carapace length of mole crabs was $3.3 \mathrm{~mm}$ at control sites but $4.4 \mathrm{~mm}$ at disposal sites. In 2000, when much greater recruitment of E. talpoida to disposal sites was recorded, there was little difference in median carapace length between the treatments (disposal: $4.2 \mathrm{~mm}$; control: $4.1 \mathrm{~mm}$ ).

\section{Clam growth under elevated turbidity}

Elevated concentrations of kaolin clay significantly reduced the proportionate (percentage change divided by 100) shell growth and weight gain of clams at the low but not at the high clam density (PERMANOVA, significant Turbidity $\times$ Density in-

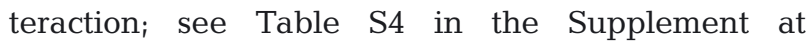
www.int-res.com/articles/suppl/m508p001_supp.pdf). Clams at high density exhibited a mean $( \pm \mathrm{SE})$ proportionate growth in shell length of $0.49 \pm 0.01$, irrespective of kaolinite, whereas clams at low density exhibited a shell growth of $0.49 \pm 0.02$ under ambient turbidity and $0.35 \pm 0.01$ under enhanced turbidity. The proportionate gain in weight was $1.61 \pm 0.10$ among clams deployed at high density in both turbid and control tanks, 1.59 \pm 0.13 in control tanks with a low clam density, and $1.11 \pm 0.08$ in turbid tanks with a low clam density. 


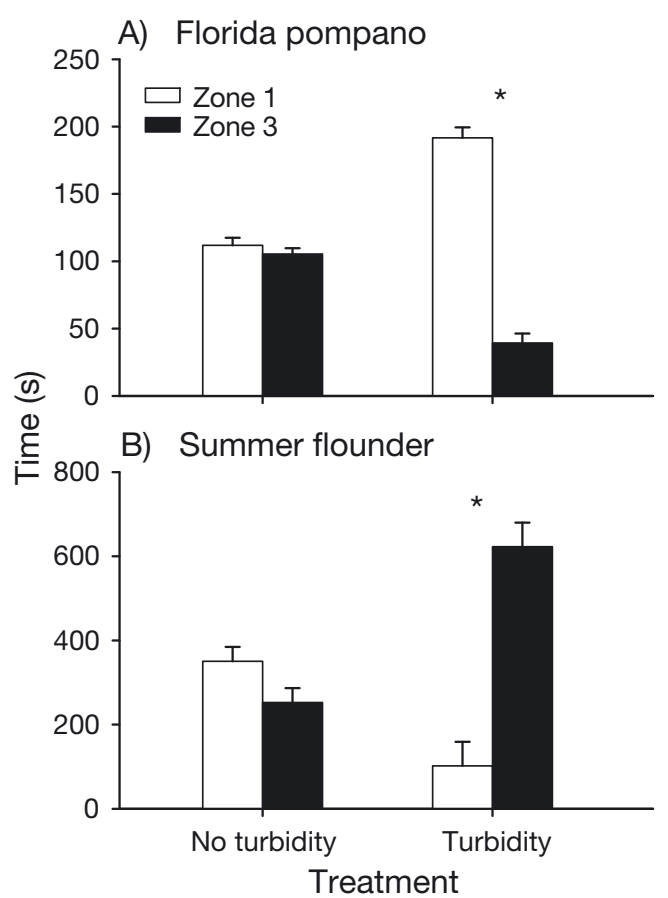

Fig. 7. Time $\left(s_{i}\right.$ mean $\left.\pm \mathrm{SE}\right)$ spent by the Florida pompano Trachinotus carolinus and summer flounder Paralichthys dentatus at 2 ends (Zones 1 \& 3) of an experimental mesocosm in the absence of turbidity, and following the addition of clear water to Zone 1 and turbid water to Zone 3 . The total duration of the experiment was $5 \mathrm{~min}(=300 \mathrm{~s})$ for pompano and $15 \min (=900 \mathrm{~s})$ for flounder $(\mathrm{n}=26$ pompano and 8 flounder). (*) Significantly different at $\alpha=0.05$ (paired $t$-test)

In tanks with a high clam density, the turbidity dropped by $64.4 \pm 11.4$ NTUs between the addition of clay and $25 \mathrm{~min}$ afterwards. In the tanks of lower clam density the drop in turbidity was, at $35.7 \pm 5.2$ NTUs, significantly less (PERMANOVA, $\mathrm{p}<0.05$ ).

\section{Response of surf fishes to turbidity}

In the absence of a turbidity difference between the 2 ends of experimental mesocosms (Zones 1 and 3 ), both the Florida pompano and the summer flounder spent similar amounts of time at each end (paired $t$-test; pompano: $t=0.67, \mathrm{df}=25, \mathrm{p}=0.509$; flounder: $t=1.17, \mathrm{df}=7, \mathrm{p}=0.280$; Fig. 7). When, however, clear water was added to one end (Zone 1) and turbid water to the other (Zone 3), the Florida pompano spent significantly more time (almost 5 -fold) in the clear water of Zone 1 than in the turbid water of Zone 3 (paired $t$-test $;=14.53, \mathrm{df}=50, \mathrm{p}<0.001$ ), while the summer flounder spent more time (over 16-fold) in the turbid Zone 3 (paired $t$-test; $t=-6.86, \mathrm{df}=7, \mathrm{p}<$ 0.001; Fig. 7).

\section{DISCUSSION}

\section{Mechanisms of disposal effects on macrobenthic infauna}

To improve mechanistic understanding of the effects that disposal of fine sediments have on sandy beach ecosystems, our study coupled field monitoring of changes in biotic and abiotic variables following each of 2 dredge spoil disposals on Topsail Island, North Carolina, with manipulative mesocosm experiments directly assessing some biological impacts of enhanced turbidity. We hypothesized that where sedimentologically fine dredge spoils were rapidly eroded from the beach following deposition, impacts to infaunal invertebrates would be short-lived. Instead, for 5 of the 6 most abundant infaunal invertebrates, we found sizeable negative impacts of dredge spoil disposal, which extended over the entire warm season of typically high abundances.

Beach profiling indicated that essentially the entire volume of sediment added in May 1999 was eroded off the beach by April 2000. Although it is possible that some of this sediment ended up in a subtidal compartment just seaward of our transects, providing some limited offshore storm protection to the beach, we would expect from its fine grain sizes that much of it was transported off the beach and then laterally in the long-shore drift. A significant reduction in sediment grain size was apparent at all elevations of the filled beaches during the warm season (over which there are naturally high infaunal abundances) following each spring nourishment event. Complete convergence of sediment properties between control and nourished beaches following the first disposal event did not occur until March 2000. Although the sustained divergence was partially explained by a natural coarsening of sediments on the control beaches over the study period, probably in response to storm activity, it also reflected the time required for the entire mass of fine sediments from the treatment beaches to be eroded.

Dredge spoil deposition induced large and statistically significant effects on abundances of all 6 numerically dominant infaunal invertebrates. Only one, the spionid polychaete Scolelepis squamata, an opportunist that has been observed to 'over-colonise' following nourishment (Leewis et al. 2012), exhibited a positive response to spoil disposal: impacts detected for each of the other 5 species were negative. Examination of whether the disposal event preceded or succeeded the major period of seasonal recruitment provides insight into the likely mechanisms 
of impact and simultaneously implies management guidance on how to minimize negative effects.

At least 4 mechanisms may help explain invertebrate responses to fine spoil disposal. (1) Mortality may have been induced through burial, crushing, and suffocation by the sediments as well as by the bulldozers used to spread them (e.g. Maurer et al. 1981, Peterson 1985, Thrush et al. 2003). (2) The turbidity generated during deposition of the slurry of dredge spoils may have clogged gills and palps of filter-feeding invertebrates, leading to mortality (Reilly \& Bellis 1983). (3) Environmental changes, such as shifts in water clarity or sedimentology, may have altered predation rates by surf fishes and hence abundance of their infaunal prey. (4) The change in grain size from medium to fine sand may have influenced habitat selection of larvae of $D$. variabilis, $E$. talpoida, and S. squamata, or juveniles of the haustoriid amphipods. The first 3 of these mechanisms, each of which involves post-recruitment mortality, require that the disposal event succeeds the spring recruitment pulses. The fourth, in contrast, requires that disposal of incompatible sediments precede some of the recruitment period.

In both years, disposal preceded recruitment in $E$. talpoida, so that the reduced abundance was presumably caused by habitat selection of the megalopae (Hayden \& Dolan 1974), which in central North Carolina exhibit their major settlement in June to July (Diaz 1980). The significant suppression of E. talpoida abundance in 1999 but not 2000 may reflect the 2-fold greater deposition of fine sediment in 1999 than 2000. However, given that in each year E. talpoida recruitment occurred after beach nourishment, such that its abundance was presumably affected more by sediment surface conditions rather than burial, the mechanism by which the effect size of the impact would be related to fill volume is not apparent.

Seasonal recruitment of $D$. variabilis, Haustorius sp. and $P$. longimerus occurred after the 1999 disposal, but before and during the 2000 disposal process. The 1999 event did not detectably influence recruitment of any of these 3 species, while the 2000 event induced a significant suppression of abundance in each. This response implies that burial and suffocation affected new recruits more than older individuals, which is supported by the fact that small bivalves like $D$. variabilis burrow through sediments much more slowly than larger ones (Nel et al. 2001). Although clogging of gills and palps by fine particles and modification of predation rates by turbidity may also explain this pattern of response expressed by these 3 species, the turbidity enhancement docu- mented during and after the spoil disposal events at North Topsail does not seem persistent enough to stand alone as an explanation. In addition, turbidity was not more intense during the 2000 event, as would be required to explain the observed lack of impacts in 1999 followed by large detectable impacts in 2000. The episodic nature of turbidity enhancement after each disposal suggests that impacts of turbidity on habitat choice or on the capacity of surf fishes to consume benthic prey is not a likely explanation for the set of common responses by these 3 macroinvertebrates.

The amphipod A. virginiana displayed virtually complete recruitment failures on nourished beaches in both years, independent of whether disposal occurred during or after the recruitment season. These recruitment failures occurred despite sustained populations at control sites, of which Topsail Dunes (C1) was perhaps close enough to provide dispersing young for this direct-developing taxon to recolonize the disturbed sites. A. virginiana, which usually inhabits the top 0 to $2.5 \mathrm{~cm}$ of sediments (Croker \& Hatfield 1980), may be more susceptible to death by burial than other amphipods. Other studies have also found that this taxon is particularly sensitive to disturbance and slow to recover (Jaramillo et al. 1987).

We reason that the only taxon to exhibit an enhancement of abundance at the disposal sites, Scolelepis squamata, was responding behaviorally to the increase in finer sediments. In laboratory experiments, however, this broadly distributed opportunistic polychaete (Leewis et al. 2012) displayed a preference for medium to fine sediment but also occupied coarse sediments (Van Tomme et al. 2013). However, the disposal events at Topsail Island succeeded the initiation of $S$. squamata recruitment in both sampling years, although substantial recruitment also continued for months after the disposal process ended. This extended recruitment season appears to be sufficient to have allowed recruiting larvae to express a preference for the finer sediments in the dredge spoil. As particle size and organic content of sediments typically co-vary (Snelgrove \& Butman 1994), the fine-grained dredge spoil was likely also high in organic matter that could provide a food supplement for this spionid polychaete.

\section{Implications for predators of benthic invertebrates}

Impacts on infauna persisted throughout the warm season of normally high densities, and recovery was not observed until the next successful major re- 
cruitment event. The net consequence of suppressing populations of $D$. variabilis, E. talpoida, and 3 haustoriid amphipods, while enhancing abundance of only the spionid polychaete S. squamata, was a large reduction in the total biomass of these invertebrates over the warmer months, because $D$. variabilis and E. talpoida are much larger than this spionid polychaete. Because benthic macroinvertebrates of sandy beaches deliver the valued ecosystem services of providing important, accessible, and dense food resources for crabs, juvenile surf fishes, and resident, migrating, and breeding shorebirds (McLachlan \& Brown 2006), spoil disposal has the potential to cause losses of prey subsidies to higher trophic levels on a local scale. Declines in these prey resources from ocean beaches can have cascading impacts on shorebirds (Dugan et al. 2003, Peterson et al. 2006, 2014) and fishes (Lasiak 1986, Hackney et al. 1996, Manning et al. 2013).

By sampling at monthly frequency during warmer months, we were able to determine whether the sediment deposition process occurred largely before or after the major period of seasonal recruitment of the 6 most abundant infaunal invertebrates of the sandy beach. This design permits insights into whether impacts of sediment deposition on benthic invertebrate resources differ depending on the timing of deposition relative to recruitment. When disposal occurred before annual recruitment to the beach (5 of 12 Species $\times$ Year combinations), it failed to induce a significant response in population abundance in 3 instances and suppressed abundance in the other 2 instances. When disposal occurred after initiation of annual recruitment, it failed to induce detectable responses in only 1 instance while suppressing population abundance in 5 instances and enhancing abundance in 1. Consequently, timing the deposition of dredged sediments to occur before recruitment season apparently has a lower risk of negative impacts on benthic infaunal abundances on the receiving beach. Massive fill of several meters depth would be expected to have direct mortality consequences on almost every species of beach invertebrate, whereas those species that express a strong larval settlement or juvenile sediment selection preference would be a subset and would include some species that may prefer the new sedimentology.

One long-standing scientific recommendation to coastal managers has been to conduct beach nourishment during the winter season of lower biological activity on ocean beaches so as to avoid interfering with important biological processes during the warmer months (Peterson et al. 2000, Greene 2002).
Although this recommendation is not consistently followed (e.g. Cooke et al. 2012), our finding that the timing of fill relative to the recruitment of fauna influences the magnitude, and even the occurence of ecological impacts, suggests that cold-season implementation may indeed enhance the ecological sustainability of beach nourishment.

Although our mesocosm study did not simultaneously manipulate the concentration of particulate organic matter or other types of fine particles present in dredge spoil, the experimental outcomes appeared to reflect one response of organisms in the field. Field sampling revealed that $D$. variabilis had smaller body lengths at disposal sites than on control beaches during almost the entire 2 yr sampling period. Although these size differences may have mostly reflected demographic differences in age distributions, stunting of growth via periodic exposure to elevated turbidity presumably also contributed to maintaining the smaller body sizes of this biomass-dominant species. The smaller body sizes of the largest prey imply further reductions in available prey biomass beyond the effects of lower abundances, especially important for migrating red knots, and dunlin, and for resident sanderlings and juvenile pompano on North Carolina beaches.

Besides negative effects on individual growth of infaunal prey, it is likely that elevated turbidity had direct effects on visually orienting predators. In mesocosm experiments, pompano avoided waters that were made turbid through the addition of suspended kaolin clay, whereas summer flounder preferred turbid waters over clearer conditions. Wilber et al. (2003) similarly demonstrated avoidance of turbidity generated from beach nourishment by the visually orienting bluefish and attraction to turbid fill sites by the northern kingfish in New Jersey. Avoidance of turbidity makes sense for visually orienting predatory fishes such as pompano (Manning \& Lindquist 2003, Manning et al. 2013) and diving seabirds such as terns (Cyrus \& Blaber 1987). In contrast, flounders are ambush predators, which, due to their camouflage by sand, do not need to be able to see farther than a few centimeters in order to capture more closely approaching prey. They may gain more in fitness by becoming further hidden from their prey than they lose through reduction of their own visual acuity. Because our experiments with suspended kaolin clay did not fully replicate the physical, chemical, and nutritional environment of enhancement of suspended solids caused by resuspension of dredge spoil, further experiments will be required to verify results. 


\section{Management implications}

As rising sea levels and an increasing frequency of violent storms from global climate change enhance risk of storm damage to oceanfront property, public support for beach nourishment appears to be growing (Peterson \& Bishop 2005). Our study suggests that beach nourishment projects utilizing fine sediments from dredge spoil have significant negative ecological impacts. The spring-time depositions of unnaturally fine sediments depressed normally abundant invertebrate populations for the entire warm season. After winter low abundances on disposal sites and control beaches, the next annual disposal event acted again to suppress warm-season infaunal abundances, thereby generating a cumulative impact from successive annual disposal events. The disappearance of virtually all the added volume of dredge spoils from the beach within a year implies that any protection it provides against storm damage dissipates rapidly. Coastal resource management should compare benefits of beach augmentation (i.e. helping to protect beachfront property against storm damage), against the ecological costs of annually repeated spoil disposals indefinitely suppressing invertebrate prey densities. Other beneficial uses of fine dredge spoil from maintenance dredging of navigation channels exist and should be considered as alternatives to sandy beach disposal. Specifically, the total area of islands in major bays and sounds has diminished greatly as sea levels have risen over the past few decades. Fine sediments from maintenance dredging can be used to elevate now inundated sections of those islands and restore habitat for wetlands that can serve to expand limited roosting, nesting, and foraging areas of waterbirds and habitat for terrapins (as was done on Poplar Island in Chesapeake Bay, www.nab.usace.army.mil/Missions/ Environmental/PoplarIsland.aspx). Similar island wetland reconstructions in bays, sounds, and estuaries may provide more beneficial uses of fine dredge spoils than sandy beach disposal.

Acknowledgements. We thank C. Tallent, T. Riley, J. Grabowski, S. Powers, and H. C. Summerson for their assistance with field and laboratory work. O. Defeo and 3 anonymous reviewers provided helpful comments on an earlier version of this manuscript. M. Kenworthy offered useful insight into fish ecology and behavior. This work was supported in part by a doctoral fellowship from the University of North Carolina, a North Carolina Fisheries Resource Grant, and North Carolina Sea Grant mini-grants. M. Bishop was supported by the Brian Robinson Fellowship and the Macquarie University Outside Studies Program during preparation of the manuscript.

\section{LITERATURE CITED}

Anderson MJ (2005) Permutational multivariate analysis of variance. Dept of Statistics, University of Auckland

Basco DR (1999) Overview of beach engineering in the United States of America. Old Dominion University, Norfolk, VA

Brazeiro A, Defeo O (1996) Macroinfaunal zonation in microtidal sandy beaches: is it possible to identify patterns in such variable environments. Estuar Coast Shelf Sci 42:523-536

Cleary WJ, Pilkey OH (1996) Cape Lookout to Cape Fear, North Carolina, regional overview. In: Cleary WJ (ed) Environmental coastal geology: Cape Lookout to Cape Fear. Carolina Geological Society, Wilmington, NC, p 87-128

Combs SM, Dowdy RH, Gupta SC, Larson WE, Gast RG (1982) Chemical properties and mineralogical characteristics of selected dredged material. J Environ Qual 11: $255-261$

Cooke BC, Jones AR, Goodwin ID, Bishop MJ (2012) Nourishment practices on Australian sandy beaches: a review. J Environ Manage 113:319-327

Croker RA, Hatfield EB (1980) Space partitioning and interactions in an intertidal sand-burrowing amphipod guild. Mar Biol 61:79-88

Cyrus DP, Blaber SJM (1987) The influence of turbidity on juvenile marine fishes in estuaries. J Exp Mar Biol Ecol 109:71-91

- Defeo O, de Alava A (1995) Effects of human activities on long-term trends in sandy beach populations: the wedge clam Donax hanleyanus in Uruguay. Mar Ecol Prog Ser 123:73-82

$>$ Defeo O, McLachlan A, Schoeman DS, Schlacher TA and others (2009) Threats to sandy beach ecosystems: a review. Estuar Coast Shelf Sci 81:1-12

> Diaz H (1980) The mole crab Emerita talpoida (Say): a case of changing life history pattern. Ecol Monogr 50:437-456

$>$ Dugan JE, Hubbard DM, McCrary MD, Pierson MO (2003) The response of macrofauna communities and shorebirds to macrophyte wrack subsidies on exposed sandy beaches of southern California. Estuar Coast Shelf Sci 58:25-40

Dugan JE, Hubbard DM, Rodil IF, Revell DL, Schroeter S (2008) Ecological effects of coastal armoring on sandy beaches. Mar Biol 29:160-170

$>$ Dugan JE, Defeo O, Jaramillo E, Jones AR and others (2010) Give beach ecosystems their day in the sun. Science 329: 1146 (abstract)

Edge BL (1972) Hydrodynamic analysis of sludge dumped in coastal waters. Coast Eng Proc 1:2187-2206

Folk RL (1980) Petrology of sedimentary rocks. Hemphill, Austin, TX

> Gorzelany JF, Nelson WG (1987) The effects of beach replenishment on the benthos of a sub-tropical Florida beach. Mar Environ Res 21:75-94

Greene K (2002) Beach nourishment: a review of the biological and physical impacts. ASMFC Habitat Management Ser No. 7, Atlantic States Marine Fisheries Commission, Washington, DC

Hackney CT, Posey MH, Ross SW, Norris AR (1996) A review and synthesis of data on surf fishes and invertebrates in the south Atlantic Bight and the potential impacts from beach nourishment. Contract Report to the US Army Engineer Wilmington District, Wilmington, NC

$>$ Hanson $\mathrm{H}$, Brampton A, Capobianco M, Dette HH and others (2002) Beach nourishment projects, practices, and objectives-a European overview. Coast Eng 47:81-111 
Hayden B, Dolan R (1974) Impacts of beach nourishment on distribution of Emerita talpoida, the common mole crab. J Waterway Harbor Coast Eng Div 100:123-132

> Hubbard DM, Dugan JE (2003) Shorebird use of an exposed sandy beach in southern California. Estuar Coast Shelf Sci 58:41-54

IPCC (Intergovernmental Panel on Climate Change) (2007) Summary for policymakers. In: Parry ML, Canziani OF, Palutikof JP, van der Linden PJ, Hanson CE (eds) Climate change 2007: impacts, adaptation and vulnerability. Contribution of Working Group II to the 4th assessment report of the IPCC. Cambridge University Press, p 7-22

Jaramillo E, Croker RA, Hatfield EB (1987) Long-term structure, disturbance, and recolonization of macroinfauna in a New Hampshire sand beach. Can J Zool 65:3024-3031

> Jaramillo E, Dugan JE, Hubbard DM, Melnick D and others (2012) Ecological implications of extreme events: footprints of the 2010 earthquake along the Chilean coast. PLoS ONE 7:e35348

Lasiak TA (1986) Juveniles, food and the surf zone habitat: implications for teleost nursery areas. S Afr J Zool 21: 51-56

> Leewis L, van Bodegom PM, Rozema J, Janssen GM (2012) Does beach nourishment have long-term effects on intertidal macroinvertebrate species abundance? Estuar Coast Shelf Sci 113:172-181

Manning LM, Lindquist N (2003) Helpful habitant or pernicious passenger: interactions between an infaunal bivalve, an epifaunal hydroid and three potential predators. Oecologia 134:415-422

> Manning LM, Peterson CH, Fegley SR (2013) Degradation of surf fish foraging habitat driven by sedimentological modifications caused by beach nourishment. Bull Mar Sci 89:83-106

Maurer D, Keck RT, Tinsman JC, Leathem WA (1981) Vertical migration and mortality of benthos in dredged material: Part II-Crustacea. Mar Environ Res 5:301-317

> McLachlan A (1980) Intertidal zonation of macrofauna and stratification of meiofauna on high-energy sandy beaches in the Eastern Cape, South Africa. Trans R Soc S Afr 44:213-223

McLachlan A (1996) Physical factors in benthic ecology: effects of changing particle size on beach fauna. Mar Ecol Prog Ser 131:205-217

McLachlan A, Brown AC (2006) The ecology of sandy shores. Academic Press, Burlington, MA

- Nel R, McLachlan A, Winter DP (2001) The effect of grain size on the burrowing of two Donax species. J Exp Mar Biol Ecol 265:219-238

Nelson WG (1988) An overview of the effects of beach nourishment on the sand beach fauna. In: Tait LS (ed) Beach preservation technology 88. Problems and advancements in beach nourishment. Florida Shore and Beach Preservation Association, Tallahassee, FL, p 295-310

Peterson CH (1985) Patterns of lagoonal bivalve mortality after heavy sedimentation and their paleoecological significance. Paleobiology 11:139-153

Peterson CH, Bishop MJ (2005) Assessing the environmental impacts of beach nourishment. Bioscience 55:887-896

Peterson CH, Hickerson DHM, Johnson GG (2000) Shortterm consequences of nourishment and bulldozing on the dominant large invertebrates of a sandy beach. J Coast Res 16:368-378

> Peterson CH, Bishop MJ, Johnson GA, D'Anna LM, Manning LM (2006) Exploiting beach filling as an unaffordable experiment: benthic intertidal impacts propagating upwards to shorebirds. J Exp Mar Biol Ecol 338:205-221

Peterson CH, Bishop MJ, D'Anna LM, Johnson GA (2014) Multi-year persistence of beach habitat degradation from nourishment using coarse shelly sediments. STOTEN 487:481-492

Pilkey OH, Wright HL (1988) Seawalls versus beaches. J Coast Res 4:41-64

Rakocinski CF, Heard RW, LeCroy SE, McLelland JA, Simons T (1996) Responses by macrobenthic assemblages to extensive beach restoration at Perdido Key, Florida, USA. J Coast Res 12:326-353

Reilly F, Bellis FJ (1983) The ecological impact of beach nourishment with dredged materials on the intertidal zone at Bogue Banks, North Carolina. CERC Misc. Report 83-3, US Army Corps of Engineers, Fort Belvoir, VA

> Robinson WE, Wehling WE, Morse MP (1984) The effect of suspended clay on feeding and digestive efficiency of the surf clam, Spisula solidissima (Dillwyn). J Exp Mar Biol Ecol 74:1-12

Rogers SM Jr (2007) Beach nourishment for hurricane protection: North Carolina project performance in Hurricanes Dennis and Floyd. Shore Beach 75:37-42

Schlacher TA, Dugan J, Schoeman DS, Lastra M and others (2007) Sandy beaches at the brink. Divers Distrib 13: 556-560

Schlacher TA, Noreiga R, Jones A, Dye T (2012) The effects of beach nourishment on benthic invertebrates in eastern Australia: impacts and variable recovery. Sci Total Environ 435/436:411-417

Snelgrove PV, Butman CA (1994) Animal-sediment relationships revisited: cause versus effect. Oceanogr Mar Biol Ann Rev 32:111-177

Speybroeck J, Bonte D, Courtens W, Gheskiere T and others (2006) Beach nourishment: an ecologically sound coastal defense alternative? A review. Aquat Conserv 16:419-435

Staudinger MD, Grimm NB, Staudt A, Carter SL and others (2012) Impacts of climate change on biodiversity, ecosystems, and ecosystem services: technical input to the 2013 national climate assessment. Cooperative Report to the 2013 National Climate Assessment. http://assessment. globalchange.gov

Thrush SF, Hewitt JE, Norkko A, Cummings VJ, Funnell GA (2003) Macrobenthic recovery processes following catastrophic sedimentation on estuarine sandflats. Ecol Appl 13:1433-1455

Valverde HR, Trembanis AC, Pilkey OH (1999) Summary of beach nourishment episodes on the U.S. East coast barrier islands. J Coast Res 15:1100-1118

- Van Tomme J, Vanden Eede S, Speybroeck J, Degraer S, Vincx M (2013) Macrofaunal sediment selectivity considerations for beach nourishment programmes. Mar Environ Res 84:10-16

Viola SM, Hubbard DM, Dugan JE, Schooler NK (2013) Burrowing inhibition by fine textured beach fill: implications for recovery of beach ecosystems. Estuar Coast Shelf Sci http://dx.doi.org/10.1016/j.ecss.2013.09.003

> Warrick JA (2013) Dispersal of fine sediment in nearshore coastal waters. J Coast Res 29:579-596

- Wilber DH, Clarke DG (2001) Biological effects of suspended sediments: a review of suspended sediment impacts on fish and shellfish with relation to dredging activities in estuaries. N Am J Fish Manage 21:855-875

Wilber DH, Clarke DG, Ray GL, Burlas M (2003) Response of surf zone fish to beach nourishment operations on the northern coast of New Jersey, USA. Mar Ecol Prog Ser 250:231-246 